\title{
Environmental concern regarding the effect of humidity and temperature on 2019-nCoV survival: fact or fiction
}

\author{
Narges Nazari Harmooshi ${ }^{1} \cdot$ Kiarash Shirbandi $^{2}$ - Fakher Rahim ${ }^{3,4}$ (D)
}

Received: 1 April 2020 / Accepted: 15 June 2020 / Published online: 26 June 2020

(C) Springer-Verlag GmbH Germany, part of Springer Nature 2020

\begin{abstract}
The new coronavirus, called 2019-nCoV, is a new type of virus that was first identified in Wuhan, China, in December 2019. Environmental conditions necessary for survival and spread of 2019-nCoV are somewhat transparent but unlike animal coronaviruses. We are poorly aware of their survival in environment and precise factors of their transmission. Countries located in east and west of globe did not have a significant impact on prevalence of disease among communities, and on the other hand, north and south have provided a model for relative prediction of disease outbreaks. The 2019-nCoV can survive for up to 9 days at $25^{\circ} \mathrm{C}$, and if this temperature rises to $30^{\circ} \mathrm{C}$, its lifespan will be shorter. The 2019-nCoV is sensitive to humidity, and lifespan of viruses in $50 \%$ humidity is longer than that of $30 \%$. Also, temperature and humidity are important factors influencing the COVID-19 mortality rate and may facilitate $2019-\mathrm{nCoV}$ transmission. Thus, considering the available and recent evidence, it seems that low temperatures, as well as dry and unventilated air, may affect stability and transmissibility of 2019-nCoV.
\end{abstract}

Keywords Environmental factors $\cdot$ Humidity $\cdot$ Temperature $\cdot$ Severe acute respiratory syndrome coronavirus 2 (SARS-CoV-2) 2019-nCoV · COVID-19

\section{Introduction}

The new coronavirus, called 2019-nCoV, is a new type of virus that was first identified in Wuhan, China, in December 2019 (Ghinai et al. 2020). The 2019-nCoV is from same family as severe acute respiratory syndrome (SARS), communityacquired pneumonia (CAP), and other common colds. The $2019-\mathrm{nCoV}$ is a relatively large virus with a size of about $1-$ $2 \mathrm{~nm}$ and is from a group of enveloped virus family,

\section{Responsible editor: Lotfi Aleya}

Fakher Rahim

Bioinfo2003@gmail.com

1 Epidemiology, Deputy of Health, Health Centre, Ahvaz Jundishapur University of Medical Sciences, Ahvaz, Iran

2 Universal Scientific Education and Research Network (USERN), Ahvaz Jundishapur University of Medical Sciences, Ahvaz, Iran

3 School of Health, Research Center of Thalassemia \& Hemoglobinopathy, Health Research Institute, Ahvaz Jundishapur University of Medical Sciences, Ahvaz, Iran

4 Clinical Research Development Unit, Golestan Hospital, Ahvaz Jundishapur University of Medical Sciences, Ahvaz, Iran containing a positive-sense single-stranded RNA (Fehr and Perlman 2015; Ebrahimi et al. 2020). The virus is transmitted through direct contact with infected person's respiratory droplets (coughing and sneezing), as well as contact with infected surfaces. The 2019-nCoV can survive for hours on surfaces, but a simple disinfectant can eliminate it (Lai et al. 2020a). COVID-19 signs and symptoms include fever, cough, and shortness of breath. In more severe cases, the infection can lead to pneumonia or respiratory severe problems, and ultimately in rare cases, the disease will be fatal (Huang et al. 2020a).

In the absence of a safe and effective vaccine, as well as a lack of specific drug treatment, the only solution is preventing its transmission, performing general education, and implementing appropriate prevention and control. Precautions can help people prevent risk of infection, such as washing hands frequently with soap and water or an alcohol-based disinfectant gel, covering mouth with your bent napkin or elbow when sneezing or coughing, avoiding close contact with those who have symptoms, and being sure to see a doctor if have a fever, cough, or difficulty breathing (Haybar et al. 2020). The virus transfers through direct and close contact with respiratory droplets of the affected person (cough or sneeze) or contact with contaminated surfaces (Ghinai et al. 
2020; Yu et al. 2020), and it can survive for hours on surfaces, but a pure disinfectant can eliminate it.

\section{The COVID-19 survival in the environment and its prevention and control}

Common coronavirus viruses spread through respiratory and gastrointestinal tracts, and nose and mouth are their two main entry routes (Fig. 1). In vulnerable and susceptible individuals, these viruses often cause only common cold that usually recovers spontaneously and has no serious side effects. However, viruses such as SARS, Middle East respiratory syndrome-related coronavirus (MERS), or 2019-nCoV can cause an acute and lethal form of pneumonia or gastritis. The risk of environmental contamination by these three types of viruses is far greater than the other viruses (Zhao et al. 2020a). The outflow and spread of the virus from the body occur within about 6 days after infection and reaches its maximum 4 days later (Jiang et al. 2020; Nishiura et al. 2020). The environmental conditions necessary for the survival and spread of 2019-nCoV are somewhat clear, but unlike animal coronaviruses, there is less and limited knowledge about the natural causes of 2019-nCoV transmission (Kamel Boulos and Geraghty 2020; Khafaie and Rahim 2020a). Although several studies on SARS-CoV have already been conducted, a limited number of studies have shown that humidity and temperature probably affect the activity and transmissibility of the 2019-nCoV (Table 1). As simply can see in the table, most of the studies reported that temperature and relative humidity could have a significant impact on the incidence rate and transmission of SARS-CoV2.

\section{Aerosols and droplets}

Epidemiologic and field studies show that 2019-nCoV, just similar to SARS and MERS, is spread through fine-grained particles (such as particles sneezing out of the mouth) (Yu et al. 2020; Schwartz and Graham 2020). In only a single old study (Tang 2009), the survival of the airborne human coronavirus $229 \mathrm{E}(\mathrm{HCV} / 229 \mathrm{E})$, a virus used in research as a representative or surrogate of coronary respiratory viruses, was studied under different temperature and relative humidity conditions. The study showed that under such conditions, the virus has a half-life of 27 and $67 \mathrm{~h}$ at $30 \%$ and $50 \%$ humidity, respectively, while its half-life at $80 \%$ humidity is only $3 \mathrm{~h}$. When the temperature drops as 6 degrees, the virus's half-life is increased $3 \mathrm{~h}$ at $80 \%$ humidity. Similar conditions and consequences have been reported for seasonal flu (Lowen and Steel 2014). This severe effect of lowering the temperature on prolonging the virus's half-life at high humidity could help the 2019-nCoV spread under these conditions. In spite of several clinical studies that claimed that spreading the virus into droplets can be prevented using appropriate masks, it is

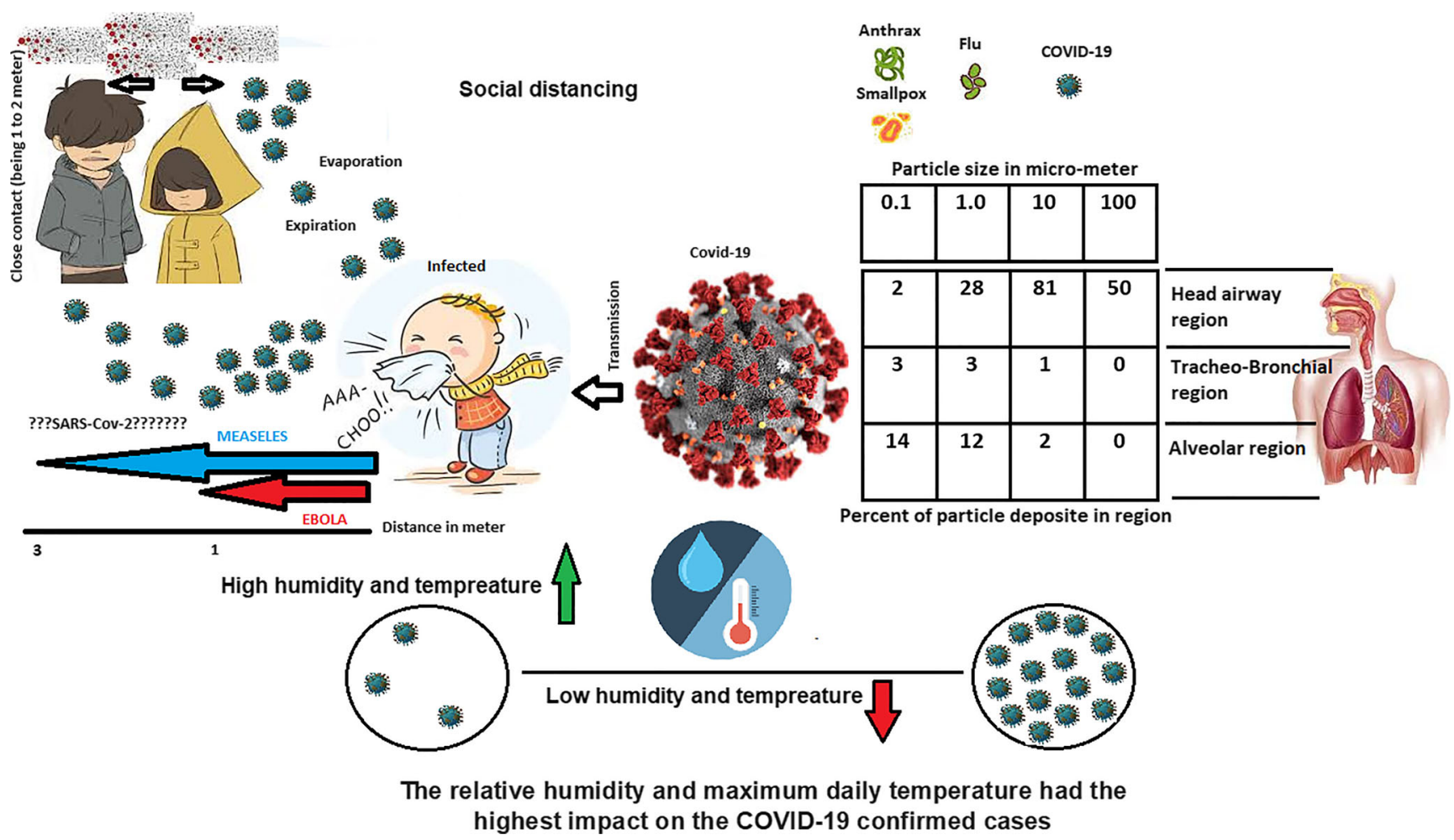

Fig. 1 The importance of social distancing, close contact, particle size, percent of virus particle deposit in various regions of the upper airway, and the effect of humidity and temperature on the 2019-nCoV activity 
Table 1 The available literature on the effect of humidity and temperature on the COVID-19 survival and activity

\begin{tabular}{|c|c|c|c|c|c|c|}
\hline \multirow[t]{2}{*}{ Reference } & \multirow{2}{*}{ Country } & \multirow{2}{*}{$\begin{array}{l}\text { Article } \\
\text { type }\end{array}$} & \multicolumn{2}{|l|}{ Studied variable } & \multirow[t]{2}{*}{ Target group } & \multirow[t]{2}{*}{ Outcome } \\
\hline & & & Temperature & Humidity & & \\
\hline $\begin{array}{l}\text { (Wang } \\
\text { et al. } \\
\text { 2020a) }\end{array}$ & China & Preprint & Air temperature & $\begin{array}{l}\text { Relative } \\
\text { humidity }\end{array}$ & $\begin{array}{l}105 \text { pairs of the virus carriers and } \\
\text { the infected from } 100 \text { Chinese } \\
\text { cities }\end{array}$ & $\begin{array}{l}\text { COVID-19 infection severity is negatively } \\
\text { related to temperature and relative } \\
\text { humidity }\end{array}$ \\
\hline $\begin{array}{l}\text { (Sajadi } \\
\quad \text { et al. } \\
\text { 2020a) }\end{array}$ & Iran & Preprint & Air temperature & $\begin{array}{l}\text { Relative } \\
\text { humidity }\end{array}$ & $\begin{array}{l}\text { Climate data from cities with } \\
\text { significant community spread } \\
\text { of COVID-19 }\end{array}$ & $\begin{array}{l}\text { Possible to predict the region's most likely } \\
\text { to be at higher risk of significant } \\
\text { community spread of COVID-19 }\end{array}$ \\
\hline $\begin{array}{l}\text { (Bukhari } \\
\text { and } \\
\text { Jameel } \\
\text { 2020a) }\end{array}$ & USA & Preprint & Air temperature & $\begin{array}{l}\text { Relative } \\
\text { humidity }\end{array}$ & $\begin{array}{l}\text { The patterns in local weather of } \\
\text { the regions affected by } \\
\text { COVID-19 }\end{array}$ & $\begin{array}{l}\text { 2019-nCoV would not spread in warm, } \\
\text { humid regions }\end{array}$ \\
\hline $\begin{array}{l}\text { (Ma et al. } \\
2020)\end{array}$ & China & Published & $\begin{array}{l}\text { Daily average } \\
\text { temperature, } \\
\text { diurnal } \\
\text { temperature } \\
\text { range (DTR) }\end{array}$ & $\begin{array}{l}\text { Relative } \\
\text { humidity }\end{array}$ & COVID-19 related to 2299 deaths & $\begin{array}{l}\text { Temperature and humidity are important } \\
\text { factors influencing COVID-19 mortality. }\end{array}$ \\
\hline $\begin{array}{l}\text { (Chan } \\
\text { et al. } \\
\text { 2011) }\end{array}$ & China & Published & Air temperature & $\begin{array}{l}\text { Relative } \\
\text { humidity }\end{array}$ & $\begin{array}{l}\text { Incidence data were collected for } \\
430 \text { sites in China and } 11 \text { top } \\
\text { countries with the highest } \\
\text { COVID-19 incidence rate }\end{array}$ & $\begin{array}{l}\text { Low temperature and humidity may } \\
\text { facilitate the } 2019-\mathrm{nCoV} \text { transmission. }\end{array}$ \\
\hline $\begin{array}{l}\text { (Shi et al. } \\
\text { 2020) }\end{array}$ & China & Preprint & $\begin{array}{l}\text { Lowest at }-10^{\circ} \mathrm{C} \\
\text { and highest at } \\
10^{\circ} \mathrm{C}\end{array}$ & $\begin{array}{l}\text { The absolute } \\
\text { humidity of } \\
\text { approxi- } \\
\text { mately } 7 \\
\text { g/m3 }\end{array}$ & $\begin{array}{l}31 \text { provincial-level regions in } \\
\text { mainland China }\end{array}$ & $\begin{array}{l}\text { Temperatures might gas positive effect on } \\
\text { the } 2019-\mathrm{nCoV} \text { incidence }\end{array}$ \\
\hline $\begin{array}{l}\text { (Rahman } \\
\text { et al. } \\
\text { 2020a) }\end{array}$ & Japan & Preprint & Air temperature & $\begin{array}{l}\text { Relative } \\
\text { humidity }\end{array}$ & $\begin{array}{l}\text { COVID-19 confirmed cases in } 31 \\
\text { different states in China and } 70 \\
\text { cities of } 11 \text { countries }\end{array}$ & $\begin{array}{l}\text { Air temperature might has a detrimental } \\
\text { impact on SARS-CoV-2 transmission }\end{array}$ \\
\hline $\begin{array}{l}\text { Roy } \\
\text { 2020) }\end{array}$ & UK & Preprint & Air temperature & $\begin{array}{l}\text { Relative } \\
\text { humidity }\end{array}$ & $\begin{array}{l}\text { COVID-19 confirmed cases in } 31 \\
\text { different states in China and } 70 \\
\text { cities of } 11 \text { countries }\end{array}$ & $\begin{array}{l}\text { Temperature and Humidity could stop and } \\
\text { arrest the 2019-nCoV outbreak }\end{array}$ \\
\hline $\begin{array}{l}\text { (Huang } \\
\quad \text { et al. } \\
\text { 2020b) }\end{array}$ & China & Published & 5 to $15^{\circ} \mathrm{C}$ & $\begin{array}{l}\text { Relative } \\
\text { humidity }\end{array}$ & $\begin{array}{l}\text { Daily numbers of COVID- } 19 \\
\text { cases. } 3,750,000 \text { confirmed } \\
\text { COVID-19 cases from } 185 \\
\text { countries/regions }\end{array}$ & $\begin{array}{l}\text { 2019-nCoV increases in the ambient } \\
\text { environment (including the surfaces of } \\
\text { objects). COVID-19 pandemic may } \\
\text { spread cyclically and outbreaks occur in } \\
\text { large cities in the mid-latitudes in autumn } \\
2020 \text {. }\end{array}$ \\
\hline $\begin{array}{l}\text { (Oliveiros } \\
\text { et al. } \\
\text { 2020) }\end{array}$ & Portugal & Preprint & Air temperature & $\begin{array}{l}\text { Relative } \\
\text { humidity }\end{array}$ & $\begin{array}{l}\text { Exponential model relating the } \\
\text { number of accumulated } \\
\text { confirmed cases }\end{array}$ & $\begin{array}{l}\text { The decrease in the rate of progression of } \\
\text { COVID-19 with the arrival of spring and } \\
\text { summer in the northern hemisphere. }\end{array}$ \\
\hline $\begin{array}{l}\text { (Islam } \\
\text { et al. } \\
\text { 2020) }\end{array}$ & UK & Preprint & Air temperature & $\begin{array}{l}\text { Relative } \\
\text { humidity }\end{array}$ & 310 regions across 116 countries & $\begin{array}{l}\text { Temperature, humidity, and wind speed } \\
\text { were inversely associated with the } \\
\text { incidence rate of COVID-19. }\end{array}$ \\
\hline $\begin{array}{l}\text { (Qi et al. } \\
\text { 2020) }\end{array}$ & China & Preprint & Air temperature & $\begin{array}{l}\text { Relative } \\
\text { humidity }\end{array}$ & Cases in 30 Chinese provinces & $\begin{array}{l}\text { Increase in average relative humidity led to } \\
\text { a decrease in the daily confirmed cases by } \\
11 \text { to } 22 \%\end{array}$ \\
\hline $\begin{array}{l}\text { (Berumen } \\
\text { et al. } \\
2020)\end{array}$ & Mexico & Preprint & Air temperature & $\begin{array}{l}\text { Relative } \\
\text { humidity }\end{array}$ & $\begin{array}{l}\text { 1,706,914 subjects diagnosed } \\
\text { between } 12-29-2019 \text { and } \\
\text { 4-15-2020 }\end{array}$ & $\begin{array}{l}\text { The larger doubling time in } \\
\text { tropical/subtropical countries is positive- } \\
\text { ly related to date of first case diagnosed } \\
\text { and temperature. }\end{array}$ \\
\hline $\begin{array}{l}\text { (Juni et al. } \\
\text { 2020) }\end{array}$ & Canada & Published & Air temperature & $\begin{array}{l}\text { Relative } \\
\text { humidity }\end{array}$ & $\begin{array}{l}144 \text { geopolitical areas worldwide } \\
(375,609 \text { cases })\end{array}$ & $\begin{array}{l}\text { Epidemic growth of COVID-19 was not } \\
\text { associated with latitude and temperature. }\end{array}$ \\
\hline $\begin{array}{l}\text { (Zhu and } \\
\text { Xie } \\
\text { 2020) }\end{array}$ & China & Published & Air temperature & $\begin{array}{l}\text { Relative } \\
\text { humidity }\end{array}$ & 122 cities were collected & $\begin{array}{l}\text { There is no evidence supporting that case } \\
\text { counts of COVID- } 19 \text { could decline when } \\
\text { the weather becomes warmer, }\end{array}$ \\
\hline $\begin{array}{l}\text { (Guo et al. } \\
\text { 2020) }\end{array}$ & China & Published & Air temperature & $\begin{array}{l}\text { Relative } \\
\text { humidity }\end{array}$ & 11 major cities in China & $\begin{array}{l}\text { The spread of disease will be suppressed as } \\
\text { the weather warms. }\end{array}$ \\
\hline
\end{tabular}


challenging to prevent it from spreading into aerosol forms, as well as the type of mask makes no significant difference (Long et al. 2020; Wang et al. 2020b). Subsequent studies showed that viruses that had become airborne aerosols and spread through defective sewage were the possible cause of the SARS coronavirus that killed lots of people in Hong Kong in 2003 (Yu et al. 2004). In the same year, only one incident in SARS contaminated 22 out of 120 passengers on a 3-h flight (Olsen et al. 2003). Surprisingly, the contamination included people who were outside the person's 2-m distance, and viruses could not be transmitted to them through aerosols and droplets (La Rosa et al. 2013). Although it is difficult to prove that the virus has spread only through aerosols and droplets, the relatively low humidity of the aircraft has undoubtedly contributed to the higher survival of the SARS virus in the particles. But a later study did not observe that transmission of SARS-associated coronavirus and suggested that the risk of transmission is not amplified aboard aircraft (Vogt et al. 2006)

A research report from Canada points to the fact that open oxygen masks can help to spread disease agents such as SARS, in fact, viruses such as SARS are transmitted through the droplets emitted from these masks (Somogyi et al. 2004). Air exhaled through the oxygen masks transmits viruses in the droplets farther away, increasing the risk of the respiratory disease spreading to health facilities. Further research is needed to fully determine that the SARS virus and similar viruses can survive and stay live and spreadable in the warm and humid environment of oxygenated air.

Research findings on the impact of humidity and temperature on the survival of the virus in airborne particulate matter indicate contrary to that. Li et al. conducted a comprehensive study on the spread of the SARS virus at the Hong Kong Hospital and found evidence of the transmission of the virus aerosols. They also suggested improving the air conditioning or ventilation system to reduce the risk of spreading such diseases (Li et al. 2005). The 2019-nCoV is claimed does not survive at temperatures above $26{ }^{\circ} \mathrm{C}$, but it can survive for approximately $5-10 \mathrm{~min}$ on the skin, 6 to $12 \mathrm{~h}$ on plastic materials, and $12 \mathrm{~h}$ on metal (Fig. 2).

\section{Skin}

Because safety and ethical considerations do not allow the COVID-19 infection test on the human specimen, researchers used human coronavirus, 229E (HCoV-229E), as a surrogate to study the survival of the coronavirus on human hands. Initial findings from these tests show that about $45 \%$ of hand-infected viruses survive and remain viable after $1 \mathrm{~h}$ (Warnes et al. 2015). Such a survival time is much longer than other viruses, such as the para-influenza virus type 3, which disappears after only $10 \mathrm{~min}$. In another study, researchers used human fingers to show that by washing only with water, the concentration of HcoV-229E was reduced by $70 \%$; however, with the use of hand-sanitized alcoholic disinfectants, the concentration of this virus decreased by $99.99 \%$ within $30 \mathrm{~s}$ (Geller et al. 2012). This study highlights the importance of effective hygiene and disinfection preventing and controlling of infectious diseases caused by coronavirus family.

\section{Food, water, and surface}

There is no evidence that corona is transmitted through food or drinking water and recreational water. One study shows that SARS in the water can survive to a very limited degree (Wang et al. 2005).

Coronavirus is more stable and more resistant to environmental surfaces than other coated viruses (Warnes et al. 2015; Otter et al. 2016). Recently, molecular methods such as PCR have been studied for the transmission of pathogens to the environmental surfaces of aircraft (Maris 1990). However, the detection of pathogenic viruses in environmental samples seems to be necessary to assess their potential ability to infect and spread the disease. Mathematical simulations also confirm the fact that environmental levels play an essential role in the spread of coronavirus in health facilities (Ikonen et al. 2018).

\section{Clothes and face mask}

Three-level biosafety has been suggested for protectivity: (1) level 1 protection (disposable hats, disposable surgical masks, disposable isolation clothing, and disposable gloves) (Wang et al. 2020c); (2) level 2 protection (level 1 but with medical protective masks such as N95, goggles or protective masks, and as outer cover a medical protective suit); (3) level 3 protection (level 2 but with the addition of face mask or a medical mask, goggles, or face mask to a full set or with an electric air filter respirator) (Pei et al. 2020).

Wearing a face mask is suggested for healthcare workers and people who have respiratory symptoms, but is not recommended for healthy people (Organization WH 2020a). Nonmedical masks made of other materials such as cotton fabric has not been well evaluated (Esposito and Principi 2020).

\section{Climate and weather}

Scientific research to date on the COVID-19 has yielded no conclusions that the COVID-19 outbreak will decline with the start of the warm season. Many researchers have said it is too early to predict whether the COVID-19 will decrease as the season progresses (Mahase 2020). Studies have hypothesized that areas where COVID-19 has suffered the most have similar weather patterns (Lipsitch et al. 2020). Countries located in the east and west of the globe did not have a significant impact on the prevalence of the disease among communities, 


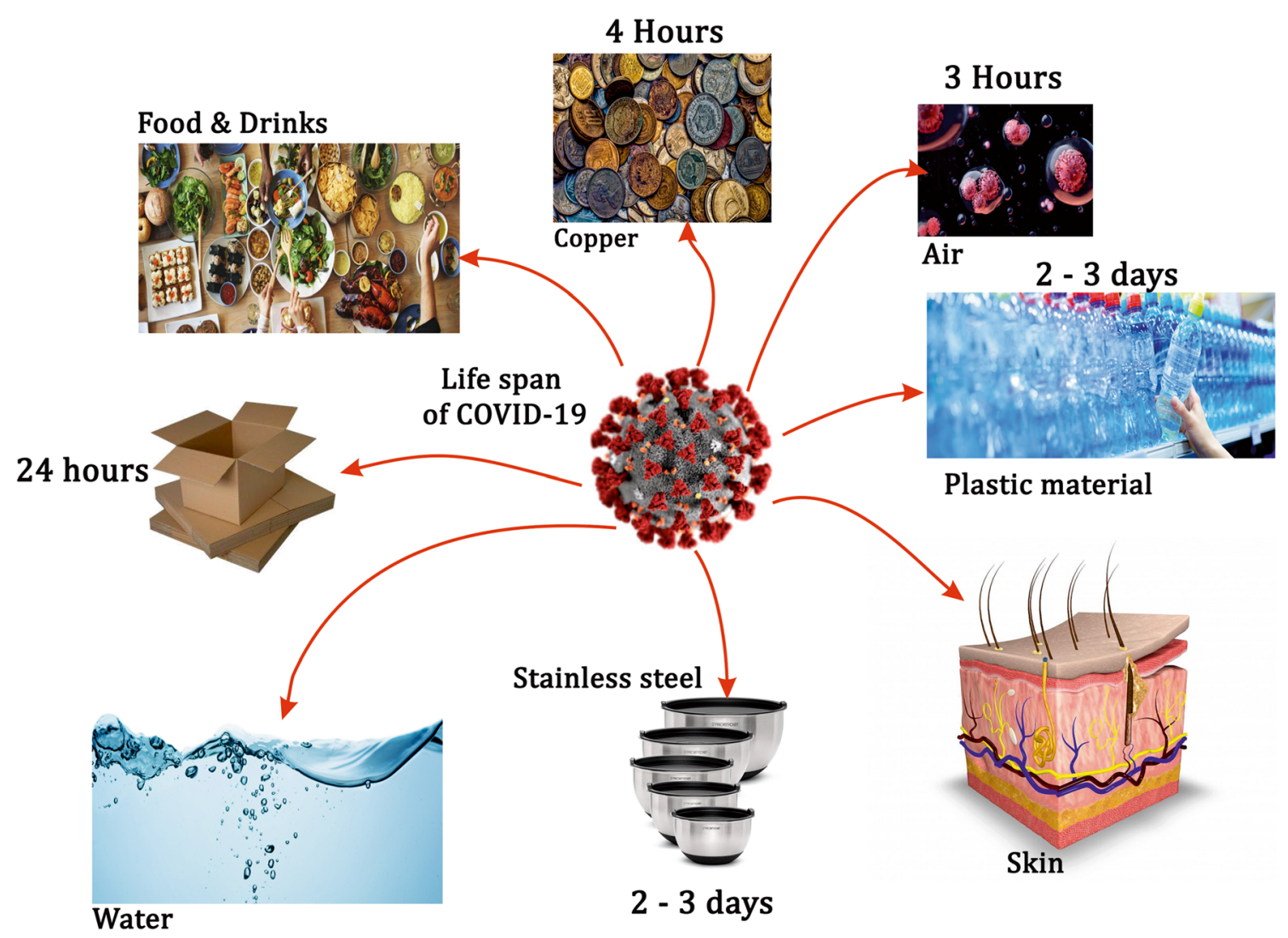

Fig. 2 Virus resilience on various surfaces and materials. Research is still underway to understand the resilience of the 2019-nCoV

and on the other hand, the north and south have provided a model for the relative prediction of disease outbreaks (Gates 2020), but now scenario has changed, and countries located on east and west of globes (USA \& Japan) have already declared emergency, and this statement was in contradiction with reality. Also, it is estimated that this disease will reach saturation in the USA in July 2020 (Arias Velásquez and Mejía Lara 2020), and outbreak of COVID-19 significantly correlated with average temperature, minimum temperature, and air quality (Bashir and Ma 2020).

There are striking similarities between average Wuhan City air temperature in January (time of outbreak here) and other polluted places in February, as well as their humidity (Vetter et al. 2020). The temperature at meteorological stations in these areas between 4 and $9{ }^{\circ} \mathrm{C}$ and in cities due to urban factors has been slightly above and between 5 and $11{ }^{\circ} \mathrm{C}$ (Sajadi et al. 2020b). It can also be predicted that with the onset of summer in northern hemisphere of the COVID-19, it may be slightly influenza-like in the tropics and spread simultaneously in the southern hemisphere (Anderson et al. 2020).

\section{Humidity and temperature}

In addition to known factors influencing the transmission of viruses, such as population displacement and human-to- human contact, environmental factors can affect transmission of droplets and the virus's survival, but for COVID-19 disease, the evidence is still very limited. Absolute humidity, which is defined as water in the ambient air, is considered a robust environmental factor for virus transmission (Huang et al. 2020b; Oliveiros et al. 2020; Islam et al. 2020; Qi et al. 2020; Berumen et al. 2020; Guo et al. 2020; Barreca and Shimshack 2012). In examining the relationship between climate and SARS-CoV-2, it is important to note that different regions of the world, which have had a high prevalence in recent weeks, have had different climates; also, no significant relationship has been found so far (Sajadi et al. 2020b) (Table 1). In analysis of regional regression, countries affected by high prevalence of disease are divided into different regions, and in these regions, climate will be examined and recorded in several changes. Then, for first period, from first day of outbreak to day of study, regression of daily aggregate growth against average temperature and relative humidity will be taken (Bukhari and Jameel 2020b). In this model, we try to control variables such as population and GDP (Table 1). However, temperature was not associated with epidemic growth of COVID-19 and case counts (Zhu and Xie 2020).

In a study by Wang et al., the effect of air temperature and relative humidity on the transmission of 2019-nCoV from 105 samples of viruses carrying infected and contaminated pairs calculated the number of daily virus production per 100 
Chinese cities with more than 40 confirmed cases. They reported that high temperatures and high humidity significantly reduced transmission of virus, respectively. Also, $1^{\circ} \mathrm{C}$ significantly reduces temperature increase and $1 \%$ decrease in relative humidity of daily virus production. Previous studies have shown that high temperature and humidity reduce the transmission of influenza and SARS, which is consistent with Wang et al.'s study. This study showed that the arrival of summer and rain in the northern hemisphere might effectively reduce 2019-nCoV transmission (Wang et al. 2020a).

In a study by Lou et al., they looked at the number of COVID-19 reproductions across China's provinces and found that rising temperatures and humidity necessitated the arrival of spring and summer in the northern hemisphere alone without extensive public health interventions. It does not reduce the number of viruses (Luo et al. 2020). Therefore, it is important to understand the impact of environmental factors on the increasing prevalence of COVID-19 to support disease control decisions (Ma et al. 2020). It is especially important in areas with high temperatures and humidity, where the risk of transmission is minimized (Shi et al. 2020). Distribution of significant disease prevalence in the community at limited latitude and longitude, temperature, and humidity is consistent with the behavior of seasonal respiratory viruses. Due to the fact that temperature and humidity are known factors in the survival of SARS-CoV, MERS-CoV, and influenza (Chan et al. 2011), the prevalence of COVID-19 in long periods of time has occurred at certain levels of temperature so that conditions of prolonged exposure to this temperature range increase the risk of disease outbreak (Rahman et al. 2020b). In addition to prolonging half-life and survival of virus, other possible mechanisms related to temperature and humidity, including droplet stabilization and increased virus spread in the nasal mucosa, like other respiratory viruses, are further evidence that these two factors affect 2019-nCoV (Schaffer et al. 1976; Shirbandi et al. 2020). It is important to note that although colder areas are relatively free of 2019-nCoV, they can affect the survival of the virus due to the low freezing cycle (Lamarre and Talbot 1989). The researchers also found that low humidity was a factor in transmission of influenza in laboratory and onset of seasonal flu (Lowen et al. 2007; Shaman et al. 2009).

Many researchers and politicians have suggested that the COVID-19 disease will go away on its own in warmer weather in the coming months in the Northern Hemisphere (Roy 2020). Some have even said that the SARS experience in 2003 is an evidence of this claim. What can now be said in response to this claim based on existing studies is that it is possible to reduce the transmission of 2019-nCoV in hot and humid weather with the closure of gathering centers such as schools and universities, but it is not logical because these reductions do not occur alone or without any effective public health-related intervention. It should be noted that even SARS does not disappear for natural reasons, but does not survive due to very severe public health interventions. These include isolating and quarantining infected people and people in contact with them, social distancing, and other targeted actions.

Therefore, it can be concluded that in case of 2019-nCoV, it is expected that, like other beta-coronaviruses, virus may be slightly more effective at low temperatures, such as in winter, although the underlying mechanism is not well-known. Therefore, the size of this change in transmission and pathogenicity of the virus is expected to be moderate and will not stop by itself. Comparing to the pandemic, the $2019-\mathrm{nCoV}$ is expected to be less immune to humans and even easily transmitted outside the cold season. Changing seasons and closing down gathering centers such as schools and universities may help, but it is unlikely to stop the transmission of the virus. To make effective policy, it is necessary to determine whether the closure of gathering centers such as schools and universities may help to reduce the rate of transfer effectively, in which if it would not be effective, the resources are wasted during such closures. For example, recent evidence suggests that children may be as susceptible as adults (Bi et al. 2020), so the critical question is whether the virus is easily transmitted under different temperature and humidity conditions. Finally, except for a limited number of articles. It is currently being published and shows that there is no conflict in the results regarding the effect of these two variables on the survival and transmission of the virus.

\section{Disinfectants}

Coated viruses such as influenza virus and coronavirus are much more vulnerable to disinfectant chemicals than other viruses such as noroviruses. Even before detection of SARS virus, disinfectants have been tested against other human and animal-infected coronaviruses. A comparative study shows that disinfectants needed to kill non-coated parvovirus are 20 to 500 times denser than disinfectants needed to kill coronavirus (Maris 1990; Lai et al. 2020b; Organization WH 2020b). The resistance of $\mathrm{HCoV}-229 \mathrm{E}$ against disinfectants has been compared with the coxsackievirus, adenovirus type 2, and influenza virus type 3 using the quantitative laboratory method, which showed that coronavirus is much more vulnerable to disinfectant chemicals than two other uninfected viruses (Maris 1990).

\section{Alcohol}

The more practical and quantitative method of QCT-2 showed that ethanol could kill $99.9 \%$ of HCoV-229E (Policy et al. n.d.). Other studies showed that alcohol-based mixture such as lozenge that contains amyl meta-cresol and dichlorobenzene alcohol could have direct and significant effects in reducing the infectivity of severe acute respiratory syndrome coronavirus (SARS-CoV) (Oxford et al. 2005; Morokutti-Kurz et al. 2017). Another research evaluated the impact of 
alcohol-based hand sanitizer on positive cases of MERS-CoV and showed that using this mixture had a significant increase in the utilized amount of virus, as well as hand hygiene compliance rates increased to $88 \%$ (Al-Tawfiq et al. 2019).

\section{Aldehyde}

Formaldehyde $4 \%$ is used as a complete sterilizer and disinfectant. However, for safety reasons, its use as a regular disinfectant is not recommended. This disinfectant can kill the TGV virus in $99.999 \%$ in 5 min, and a $2 \%$ solution can kill more than $99.9 \%$ of HCoV-229E (Sattar et al. 1989).

\section{Phenolics}

Phenolic-based ingredients have a long history of using coal tar soap with creosol. Although some disinfectants use the same historically active chemical, changes in creosol have been made to make them more effective against germs. For example, o-phenyl phenol with a concentration of $200 \mathrm{ppm}$ is quite effective against coronavirus (Sattar et al. 1989). However, adding detergent or ethanol can increase its effectiveness and eliminate $99.9 \%$ of the HCoV-229E within 5 min. Similarly, chemicals made from phenolics need other helpers to be effective (Shah et al. 2020).

\section{Possible trials ongoing of vaccine}

Many studies were ongoing (according to ClinicalTrials.gov database). According to this database, Bacillus CalmetteGuérin (BCG) vaccine, which primarily used against tuberculosis (TB), will be intervening. Other vaccines such as inactivated SARS-CoV-2 vaccine, LV-SMENP-DC vaccine, measles-mumps-rubella vaccine, autologous dendritic cells loaded with SARS-CoV-2 antigens (AV-COVID-19), ChAdOx1 nCoV-19, angiotensin-converting enzyme (ACE) inhibitors or angiotensin II receptor blocker (ARB), IgM and IgG antibodies, VPM1002 (development of the BCG vaccine) , and adoptive cellular transfer (ACT) are ongoing. There are no Food and Drug Administration (FDA)-approved vaccines to prevent or trial COVID-19. However, FDA issued Emergency Use Authorization (EUA) for emergency use of remdesivir for the treatment of hospitalized COVID-19 patients (Grein et al. 2020).

\section{Discussion}

The scientific evidence in this review article suggests that the spread of 2019-nCoV may be influenced by climatic variables such as temperature and humidity. Apparently, warm, humid weather may indicate less transmission of the 2019-nCoV.
Considering the topic that seems to impose both the positive and negative data on the possible effect of environmental factors, especially humidity and temperature on the stability and transmissibility of the 2019-nCoV, almost all available evidence revealed the possible positive effect.

Countries located in the east and west of the globe did not have a significant impact on the prevalence of the disease among communities, and on the other hand, the north and south have provided a model for the relative prediction of disease outbreaks (Gates 2020). The government and public health organizations can take steps to reduce the rate of COVID-19 transmission in the future. For example, in addition to helping their people, leading countries can help low- and middleincome countries (LMICs) prepare for the epidemic and most effectively fight against the disease (Khadka et al. 2020).

Many LMIC health systems are now vulnerable, and a pathogen such as COVID-19 can quickly lead to serious problems and challenges and eventually collapse of healthcare system. Given the natural inclination of richer countries to give priority to their own people over other countries, this has led to a political and economic leverage in poor countries. Pioneer countries can save the lives of their own people by slowing the global transmission of the COVID-19 by helping to prepare African and South Asian countries to fight the disease (Gates 2020).

Helping LMIC is essential to strengthening the primary care system with the infrastructure to fight epidemics. Welltrained healthcare workers not only provide vaccines but also monitor disease patterns as part of early warning systems that warn the world of a possible outbreak. Given the limited testing capacity in African countries, the numbers of confirmed cases of COVID-19 may greatly underestimate the true burden, although there was little evidence of unexplained outbreaks of the virus. At face value, the figures suggest that an African continent people had suffered fewer COVID-19 deaths than the top list countries such as USA, Russia, and UK (Zhao et al. 2020b; Khafaie and Rahim 2020b).

According to epidemiologists, $2019-\mathrm{nCoV}$ is not among the thermophile viruses, so it will become inactive once the cold season begins. However, others suggested that 2019$\mathrm{nCoV}$ disappears at $30{ }^{\circ} \mathrm{C}$, which is a misconception about the virus. It is also reported in the multimedia that it is better to use fried food to eliminate COVID-19, while the virus is coldfriendly and will survive longer with lower temperatures. Based on the results of new studies on the 2019-nCoV, the virus can survive on the surface for 4 to 28 days, but if the temperature drops to less than 30 to $40{ }^{\circ} \mathrm{C}$, the life span of the virus will be reduced rather than eliminated (Casanova et al. 2010). Some scholars think that if the temperature reaches 30 ${ }^{\circ} \mathrm{C}$, the virus will not survive, which is a misconception, because at this temperature, the virus's survival will reduce and does not mean that the virus will completely eliminate (Wang et al. 2020a). Since the bats' body temperature is $48^{\circ} \mathrm{C}$, so the 2019-nCoV has nothing to do with these creatures (Levesque 
et al. 2016). The virus is also sensitive to humidity in addition to temperature; therefore, SARS coronavirus and possibly 2019-nCoV have a longer life span of 50\% than 30\% humidity (Chan et al. 2011). According to published data, the human coronavirus can survive at temperatures of $20^{\circ} \mathrm{C}$ for up to 9 days, and if the temperature rises to more than $30^{\circ} \mathrm{C}$, it perhaps decreases 2019-nCoV viability, but the lower the temperature is associated with the more virus activity, in such a way that it can continue its activity for up to 28 days (Casanova et al. 2010). Thus, the most effective way to reduce the activity of this virus is to use disinfectants such as ethanol $70 \%$. These types of substances can kill the virus within a short minute.

Currently, in a modeling study, using the classification of COVID-19 confirmed cases was investigated as one of the epidemic diseases. Consequentially, the average daily temperature and relative humidity of Hubei Province in China and the number of COVID-19 confirmed cases were selected. They demonstrated that the relative humidity and the maximum daily temperature had the highest impact on the confirmed cases. The daily temperature and relative humidity affected 2019-nCoV positively, and extreme daily temperature, with an average of $15.4^{\circ} \mathrm{C}$, affected this virus negatively (Pirouz et al. 2020). Recently, a published evidence reports that 2019-nCoV significantly contaminates air, surface environment, and protective equipment by droplets of an infected person, meaning that environment is an important issue to consider because it is a potential medium of transmission; thus, it is necessary for strict adherence to environmental and personal protection and hygiene, as well as social distancing (Ong et al. 2020).

\section{Limitations}

We are poorly aware of their survival in the environment and the precise factors of their transmission. However, limited studies in this field show that $2019-\mathrm{nCoV}$ is more resistant to environmental factors than other coated viruses. The environmental conditions necessary for the survival and spread of 2019-nCoV are somewhat clear, but unlike animal coronaviruses. The effect of humidity and temperature on the 2019-nCoV activity is controversial. Researchers in the field of epidemiologists believe that the $2019-\mathrm{nCoV}$ is not a thermophilic virus, so it will be activated with the onset of the cold season.

\section{Conclusion and future direction}

According to published data, human coronavirus can survive for up to 9 days at $25^{\circ} \mathrm{C}$, and if this temperature rises to $30^{\circ} \mathrm{C}$, its lifespan will be shorter. The $2019-\mathrm{nCoV}$ is sensitive to humidity, and the lifespan of viruses in $50 \%$ humidity is longer than that of $30 \%$. Also, temperature and humidity are important factors influencing the COVID-19 mortality rate and may facilitate 2019-nCoV transmission. Seasonal factors are recognized to play an essential role in the transmission of viruses responsible for various respiratory diseases. Besides, most of these diseases reach epidemic proportions and key outbreak during winter. Recently, researchers claimed that the two main causes contribute to the description of any association between viral outbreak and the seasonal factors, including changes in environmental parameters and human behavior. Specifically, changes in temperature and humidity disturb the viral stability and transmissibility. Thus, considering the recent and available evidence, it seems that low temperature, as well as dry and unventilated air, may affect the stability and transmissibility of the 2019-nCoV.

\section{Compliance with ethical standards}

Conflict of interest The authors declare that they have no conflict of interest.

\section{References}

Al-Tawfiq JA, Abdrabalnabi R, Taher A, Mathew S, Rahman KA (2019) Infection control influence of Middle East respiratory syndrome coronavirus: a hospital-based analysis. Am J Infect Control 47(4): 431-434

Anderson RM, Heesterbeek H, Klinkenberg D, Hollingsworth TD (2020) How will country-based mitigation measures influence the course of the COVID-19 epidemic? Lancet 395(10228):931-934

Arias Velásquez RM, Mejía Lara JV (2020) Forecast and evaluation of COVID-19 spreading in USA with reduced-space Gaussian process regression. Chaos Solitons Fractals 136:109924

Barreca AI, Shimshack JP (2012) Absolute humidity, temperature, and influenza mortality: 30 years of county-level evidence from the United States. Am J Epidemiol 176(Suppl 7):S114-S122

Bashir MF, Ma B (2020) Bilal, Komal B, Bashir MA, Tan D, et al. Correlation between climate indicators and COVID-19 pandemic in New York, USA. Sci Total Environ 728:138835

Berumen J, Schmulson M, Guerrero G, Barrera E, Larriva-Sahd J, Olaiz G, Garcia-Leyva R, Wong-Chew RM, Betancourt-Cravioto M, Gallardo H, Fajardo-Dolci G (2020) Trends of SARS-Cov-2 infection in 67 countries: role of climate zone, temperature, humidity and curve behavior of cumulative frequency on duplication time. medRxiv. Preprint

Bi Q, Wu Y, Mei S, Ye C, Zou X, Zhang Z, et al (2020) Epidemiology and transmission of COVID-19 in Shenzhen China: analysis of 391 cases and 1,286 of their close contacts. 2020.03.03.20028423

Bukhari Q, Jameel Y (2020a) Will coronavirus pandemic diminish by summer? SSRN. Preprint (March 17)

Bukhari Q, Jameel Y (2020b) Will coronavirus pandemic diminish by summer? Available at SSRN 3556998

Casanova LM, Jeon S, Rutala WA, Weber DJ, Sobsey MD (2010) Effects of air temperature and relative humidity on coronavirus survival on surfaces. Appl Environ Microbiol 76(9):2712-2717

Chan KH, Peiris JS, Lam SY, Poon LL, Yuen KY, Seto WH (2011) The effects of temperature and relative humidity on the viability of the SARS coronavirus. Adv Virol 2011:734690 
Ebrahimi M, Saki Malehi A, Rahim F (2020) COVID-19 infection in medical staffs versus patients: a systematic review and metaanalysis of laboratory findings, comorbidities, and clinical outcome. Fakher, COVID-19 Infection in Medical Staffs versus Patients: A Systematic Review and Meta-analysis of Laboratory Findings, Comorbidities, and Clinical Outcome (April 20, 2020)

Esposito S, Principi N (2020) To mask or not to mask children to overcome COVID-19. Eur J Pediatr 1-4. https://doi.org/10.1007/ s00431-020-03674-9

Fehr AR, Perlman S (2015) Coronaviruses: an overview of their replication and pathogenesis. Methods Mol Biol (Clifton, NJ) 1282:1-23

Gates B (2020) Responding to Covid-19 - A Once-in-a-Century Pandemic?. N Engl J Med 382(18):1677-1679. https://doi.org/10. 1056/NEJMp2003762

Geller C, Varbanov M, Duval RE (2012) Human coronaviruses: insights into environmental resistance and its influence on the development of new antiseptic strategies. Viruses. 4(11):3044-3068

Ghinai I, McPherson TD, Hunter JC, Kirking HL, Christiansen D, Joshi K, Rubin R, Morales-Estrada S, Black SR, Pacilli M, Fricchione MJ, Chugh RK, Walblay KA, Ahmed NS, Stoecker WC, Hasan NF, Burdsall DP, Reese HE, Wallace M, Wang C, ... Illinois COVID19 Investigation Team (2020) First known person-to-person transmission of severe acute respiratory syndrome coronavirus 2 (SARSCoV-2) in the USA. Lancet (London, England) 395(10230):11371144. https://doi.org/10.1016/S0140-6736(20)30607-3

Grein J, Ohmagari N, Shin D, Diaz G, Asperges E, Castagna A, Feldt T, Green G, Green ML, Lescure FX, Nicastri E, Oda R, Yo K, QuirosRoldan E, Studemeister A, Redinski J, Ahmed S, Bernett J, Chelliah D, Chen D, Chihara S, Cohen SH, Cunningham J, D'Arminio Monforte A, Ismail S, Kato H, Lapadula G, L'Her E, Maeno T, Majumder S, Massari M, Mora-Rillo M, Mutoh Y, Nguyen D, Verweij E, Zoufaly A, Osinusi AO, DeZure A, Zhao Y, Zhong L, Chokkalingam A, Elboudwarej E, Telep L, Timbs L, Henne I, Sellers S, Cao H, Tan SK, Winterbourne L, Desai P, Mera R, Gaggar A, Myers RP, Brainard DM, Childs R, Flanigan T (2020) Compassionate use of remdesivir for patients with severe Covid-19. N Engl J Med 382:2327-2336

Guo X-J, Zhang H, Zeng Y-P (2020) Transmissibility of COVID-19 and its association with temperature and humidity

Haybar H, Kazemnia K, Rahim F (2020) Underlying chronic disease and COVID-19 infection: A State-of-the-Art Review. Jundishapur J Chronic Dis Care 9(2):e103452

Huang C, Wang Y, Li X, Ren L, Zhao J, Hu Y, Zhang L, Fan G, Xu J, Gu X, Cheng Z, Yu T, Xia J, Wei Y, Wu W, Xie X, Yin W, Li H, Liu M, Xiao Y, ... Cao B (2020a) Clinical features of patients infected with 2019 novel coronavirus in Wuhan, China. Lancet (London, England) 395(10223):497-506. https://doi.org/10.1016/S0140-6736(20)30183-5

Huang Z, Huang J, Gu Q, Du P, Liang H, Dong Q (2020b) Optimal temperature zone for the dispersal of COVID-19. Sci Total Environ 139487

Ikonen N, Savolainen-Kopra C, Enstone JE, Kulmala I, Pasanen P, Salmela A et al (2018) Deposition of respiratory virus pathogens on frequently touched surfaces at airports. BMC Infect Dis 18(1):1-7

Islam N, Shabnam S, Erzurumluoglu AM (2020) Temperature, humidity, and wind speed are associated with lower Covid-19 incidence. medRxiv. Preprint

Jiang X, Rayner S, Luo MH (2020) Does SARS-CoV-2 has a longer incubation period than SARS and MERS? J Med Virol 92(5):476-478

Juni P, Rothenbuhler M, Bobos P, Thorpe KE, da Costa BR, Fisman DN et al (2020) Impact of climate and public health interventions on the COVID-19 pandemic: a prospective cohort study. CMAJ. 192: E566-E573

Kamel Boulos MN, Geraghty EM (2020) Geographical tracking and mapping of coronavirus disease COVID-19/severe acute respiratory syndrome coronavirus 2 (SARS-CoV-2) epidemic and associated events around the world: how 21 st century GIS technologies are supporting the global fight against outbreaks and epidemics. Int $\mathrm{J}$ Health Geogr 19(1):8

Khadka S, Hashmi FK, Usman M (2020) Preventing COVID-19 in lowand middle-income countries. Drugs \& therapy perspectives : for rational drug selection and use, 1-3. https://doi.org/10.1007/ s40267-020-00728-8

Khafaie MA, Rahim F (2020a) Cross-country comparison of case fatality rates of COVID-19/SARS-COV-2. Osong Public Health Res Perspect 11(2):74-80

Khafaie MA, Rahim F (2020b) Estimating case fatality rate of symptomatic patients with COVID-19: is this the right thing to do? Available at SSRN 3591068

La Rosa G, Fratini M, Della Libera S, Iaconelli M, Muscillo M (2013) Viral infections acquired indoors through airborne, droplet or contact transmission. Ann Ist Super Sanita 49(2):124-132

Lai CC, Liu YH, Wang CY, Wang YH, Hsueh SC, Yen MY, Ko WC, Hsueh PR (2020a) Asymptomatic carrier state, acute respiratory disease, and pneumonia due to severe acute respiratory syndrome coronavirus 2 (SARS-CoV-2): Facts and myths. Journal of Microbiology, Immunology, and Infection = Wei mian yu gan ran za zhi 53(3):404-412. https://doi.org/10.1016/j.jmii.2020.02.012

Lai CC, Shih TP, Ko WC, Tang HJ, Hsueh PR (2020b) Severe acute respiratory syndrome coronavirus 2 (SARS-CoV-2) and coronavirus disease-2019 (COVID-19): The epidemic and the challenges. Int J Antimicrob Agents 55(3):105924. https://doi.org/10.1016/j. ijantimicag.2020.105924

Lamarre A, Talbot PJ (1989) Effect of $\mathrm{pH}$ and temperature on the infectivity of human coronavirus 229E. Can J Microbiol 35(10):972-974

Levesque DL, Nowack J, Stawski C (2016) Modelling mammalian energetics: the heterothermy problem. Clim Chang Responses 3(1):7

Li Y, Huang X, Yu IT, Wong TW, Qian H (2005) Role of air distribution in SARS transmission during the largest nosocomial outbreak in Hong Kong. Indoor Air 15(2):83-95

Lipsitch M, Swerdlow DL, Finelli L (2020) Defining the epidemiology of Covid-19—-studies needed. N Engl J Med 382:1194-1196

Long Y, Hu T, Liu L, Chen R, Guo Q, Yang L, Cheng Y, Huang J, du L (2020) Effectiveness of N95 respirators versus surgical masks against influenza: a systematic review and meta-analysis. J Evid Based Med 13:93-101

Lowen AC, Steel J (2014) Roles of humidity and temperature in shaping influenza seasonality. J Virol 88(14):7692-7695

Lowen AC, Mubareka S, Steel J, Palese P (2007) Influenza virus transmission is dependent on relative humidity and temperature. PLoS Pathog 3(10):1470-1476

Luo W, Majumder MS, Liu D, Poirier C, Mandl KD, Lipsitch M, et al (2020) The role of absolute humidity on transmission rates of the COVID-19 outbreak. 2020.02.12.20022467

Ma Y, Zhao Y, Liu J, He X, Wang B, Fu S, Yan J, Niu J, Zhou J, Luo B (2020) Effects of temperature variation and humidity on the death of COVID-19 in Wuhan, China. Sci Total Environ 724:138226. https://doi.org/10.1016/j.scitotenv.2020.138226

Mahase E (2020) Covid-19: 90\% of cases will hit NHS over nine week period, chief medical officer warns. BMJ (Clinical Research ed.) 368:m918. https://doi.org/10.1136/bmj.m918

Maris P (1990) Virucidal efficacy of eight disinfectants against pneumovirus, coronavirus and parvovirus. Ann Rech Vet 21(4): 275-279

Morokutti-Kurz M, Graf C, Prieschl-Grassauer E (2017) Amylmetacresol/2,4-dichlorobenzyl alcohol, hexylresorcinol, or carrageenan lozenges as active treatments for sore throat. Int J Gen Med 10:53-60

Nishiura H, Linton NM, Akhmetzhanov AR (2020) Serial interval of novel coronavirus (COVID-19) infections. International Journal of Infectious Diseases : IJID : Official Publication of the International Society for Infectious Diseases 93:284-286. https://doi.org/10. 1016/j.ijid.2020.02.060 
Oliveiros B, Caramelo L, Ferreira NC, Caramelo F (2020) Role of temperature and humidity in the modulation of the doubling time of COVID-19 cases. medRxiv

Olsen SJ, Chang HL, Cheung TY, Tang AF, Fisk TL, Ooi SP et al (2003) Transmission of the severe acute respiratory syndrome on aircraft. N Engl J Med 349(25):2416-2422

Ong SWX, Tan YK, Chia PY, Lee TH, Ng OT, Wong MSY, Marimuthu $\mathrm{K}$ (2020) Air, surface environmental, and personal protective equipment contamination by severe acute respiratory syndrome coronavirus 2 (SARS-CoV-2) from a symptomatic patient. JAMA. 323:1610

Organization WH (2020a) Preparedness, prevention and control of COVID-19 in prisons and other places of detention (2020), Interim guidance 15 March 2020

Organization WH (2020b) Water, sanitation, hygiene and waste management for COVID-19: technical brief, 03 March 2020. World Health Organization

Otter J, Donskey C, Yezli S, Douthwaite S, Goldenberg S, Weber D (2016) Transmission of SARS and MERS coronaviruses and influenza virus in healthcare settings: the possible role of dry surface contamination. J Hosp Infect 92(3):235-250

Oxford JS, Lambkin R, Gibb I, Balasingam S, Chan C, Catchpole A (2005) A throat lozenge containing amyl meta cresol and dichlorobenzyl alcohol has a direct virucidal effect on respiratory syncytial virus, influenza A and SARS-CoV. Antivir Chem Chemother 16(2):129-134

Pei S, Xue Y, Zhao S, Alexander N,Mohamad G, Chen X, Yin M (2020) Occupational skin conditions on the front line: a survey among 484 Chinese healthcare professionals caring for Covid-19 patients. J Eur Acad Dermatol Venereol. https://doi.org/10.1111/jdv.16570

Pirouz B, Shaffiee Haghshenas S, Shaffiee Haghshenas S, Piro P (2020) Investigating a serious challenge in the sustainable development process: analysis of confirmed cases of COVID-19 (new type of coronavirus) through a binary classification using artificial intelligence and regression analysis. Sustainability. 12(6):2427

Policy A, Prize NC, Funding G, Webzine NS (n.d.) Council A. COVID19 is an emerging, rapidly evolving situation

Qi H, Xiao S, Shi R, Ward MP, Chen Y, Tu W, Su Q, Wang W, Wang X, Zhang Z (2020) COVID-19 transmission in Mainland China is associated with temperature and humidity: a time-series analysis. Sci Total Environ 728:138778. https://doi.org/10.1016

Rahman MA, Hossain MG, Singha AC, Islam MS, Islam MA (2020a) A retrospective analysis of influence of environmental/air temperature and relative humidity on SARS-CoV-2 outbreak. Preprint. 2020030325

Rahman MA, Hossain MG, Singha AC, Islam MS, Islam MA (2020b) A retrospective analysis of influence of environmental/air temperature and relative humidity on SARS-CoV-2 outbreak

Roy I (2020) Combating recent pandemic of COVID-19 - an urgent solution. Preprint. 2020030366

Sajadi MM, Habibzadeh P, Vintzileos A, Shokouhi S, Miralles-Wilhelm F, Amoroso A (2020a) Temperature, humidity and latitude analysis to predict potential spread and seasonality for COVID-19. SSRN. Preprint

Sajadi MM, Habibzadeh P, Vintzileos A, Shokouhi S, Miralles-Wilhelm F, Amoroso A (2020b) Temperature and latitude analysis to predict potential spread and seasonality for COVID-19. Available at SSRN 3550308

Sattar S, Springthorpe V, Karim Y, Loro P (1989) Chemical disinfection of non-porous inanimate surfaces experimentally contaminated with four human pathogenic viruses. Epidemiol Infect 102(3):493-505

Schaffer FL, Soergel ME, Straube DC (1976) Survival of airborne influenza virus: effects of propagating host, relative humidity, and composition of spray fluids. Arch Virol 51(4):263-273

Schwartz DA, Graham AL (2020) Potential maternal and infant outcomes from (Wuhan) coronavirus 2019-nCoV infecting pregnant women: lessons from SARS, MERS, and other human coronavirus infections. Viruses 12(2):194. https://doi.org/10.3390/v12020194

Shah I, Shah MA, Nawaz MA, Pervez S, Noreen N, Vargas-de la Cruz C, et al (2020) Analysis of other phenolics (capsaicin, gingerol, and alkylresorcinols). Recent Advances in Natural Products Analysis: Elsevier. p. 255-71

Shaman J, Pitzer V, Viboud C, Lipsitch M, Grenfell B (2009) Absolute humidity and the seasonal onset of influenza in the continental US. PLoS Curr 2:Rrn1138

Shi P, Dong Y, Yan H, Li X, Zhao C, Liu W, et al. (2020) The impact of temperature and absolute humidity on the coronavirus disease 2019 (COVID-19) outbreak - evidence from China. medRxiv. 2020.03.22.20038919

Shirbandi K, Barghandan S, Mobinfar O, Rahim F (2020) Inactivation of coronavirus with ultraviolet irradiation: What? How? Why

Somogyi R, Vesely AE, Azami T, Preiss D, Fisher J, Correia J, Fowler RA (2004) Dispersal of respiratory droplets with open vs closed oxygen delivery masks: implications for the transmission of severe acute respiratory syndrome. Chest. 125(3):1155-1157

Tang JW (2009) The effect of environmental parameters on the survival of airborne infectious agents. J R Soc Interface 6(Suppl 6):S737-S746

Vetter P, Eckerle I, Kaiser L (2020) Covid-19: a puzzle with many missing pieces. British Medical Journal Publishing Group

Vogt TM, Guerra MA, Flagg EW, Ksiazek TG, Lowther SA, Arguin PM (2006) Risk of severe acute respiratory syndrome-associated coronavirus transmission aboard commercial aircraft. J Travel Med 13(5):268-272

Wang XW, Li J, Guo T, Zhen B, Kong Q, Yi B, Li Z, Song N, Jin M, Xiao W, zhu X, Gu C, Yin J, Wei W, Yao W, Liu C, Li J, Ou G, Wang M, Fang T, Wang G, Qiu Y, Wu H, Chao F, Li J (2005) Concentration and detection of SARS coronavirus in sewage from Xiao Tang Shan Hospital and the 309th Hospital of the Chinese People's Liberation Army. Water Sci Technol 52(8):213-221

Wang J, Tang K, Feng K, Lv W (2020a) High temperature and high humidity reduce the transmission of COVID-19. SSRN. preprint

Wang X, Pan Z, Cheng Z (2020b) Association between 2019-nCoV transmission and N95 respirator use. J Hospital Infect 105(1):104 105. https://doi.org/10.1016/j.jhin.2020.02.021

Wang X, Zhang X, He J (2020c) Challenges to the system of reserve medical supplies for public health emergencies: reflections on the outbreak of the severe acute respiratory syndrome coronavirus 2 (SARS-CoV-2) epidemic in China. Biosci Trends 14(1):3-8

Warnes SL, Little ZR, Keevil CW (2015) Human coronavirus 229E remains infectious on common touch surface materials. MBio. 6(6): e01697-e01615

Yu IT, Li Y, Wong TW, Tam W, Chan AT, Lee JH et al (2004) Evidence of airborne transmission of the severe acute respiratory syndrome virus. N Engl J Med 350(17):1731-1739

Yu YX, Sun L, Yao K, Lou XT, Liang X, Zhao BW et al (2020) Consideration and prevention for the aerosol transmission of 2019 novel coronavirus. Zhonghua Yan Ke Za Zhi 56(0):E008

Zhao D, Yao F, Wang L, Zheng L, Gao Y, Ye J, et al (2020a) A comparative study on the clinical features of COVID-19 pneumonia to other pneumonias. Clinical infectious diseases: an official publication of the Infectious Diseases Society of America

Zhao Z, Li X, Liu F, Zhu G, Ma C, Wang L (2020b) Prediction of the COVID-19 spread in African countries and implications for prevention and control: a case study in South Africa, Egypt, Algeria, Nigeria, Senegal and Kenya. Sci Total Environ 729:138959

Xie, J., \& Zhu, Y. (2020). Association between ambient temperature and COVID-19 infection in 122 cities from China. Sci Total Environ 724:138201. https://doi.org/10.1016/j.scitotenv.2020.138201

Publisher's note Springer Nature remains neutral with regard to jurisdictional claims in published maps and institutional affiliations. 